\title{
Ensuring dynamic strategic fit of firms that compete globally in alliances and networks: proposing the Global SNA - Strategic Network Analysis - framework*
}

\author{
T. Diana L. van Aduard de Macedo-Soares, PhD**
}

SummaRY: 1. Introduction; 2. Research methods; 3. Results of the literature review; 4. Theoretical positioning; 5. Introducing the Global SNA framework; 6. Discussion and concluding remarks.

Sumário: I. Introdução; 2. Métodos de pesquisa; 3. Resultados da revisão da literatura; 4. Posicionamento teórico; 5. Introduzindo o Arcabouço SNA Global; 6. Discussão e considerações finais.

KEY worDs: global strategy; transnational strategy; global strategic alliances; global strategic networks of linkages; dynamic strategic fit; relational strategic analysis; global relational network perspective; international perspective.

Palavras-chave: estratégia global; estratégia transnacional; alianças estratégicas globais; redes de ligações estratégicas globais; adequação estratégica dinâmica; análise estratégica relacional; perspectiva global relacional de rede; perspectiva internacional.

In order to sustain their competitive advantage in the current increasingly globalized and turbulent context, more and more firms are competing globally in alliances and networks that oblige them to adopt new managerial paradigms and tools. However, their strategic analyses rarely take into account the strategic implications of these alliances and networks, considering their global relational characteristics, admittedly because of a lack of adequate tools to do so. This paper contributes to research that

\footnotetext{
* Article received in May 2010 and accepted in Dec. 2010. A preliminary version of this paper was presented at the Strategic Management Society — SMS Special Conference, March 2010.

$* * \mathrm{PhD}$, University of Montreal, Canada. Full Professor in IAG — Pontifical Catholic University of Rio de Janeiro/Business School (PUC-Rio). Adress: Rua Marquês de São Vicente 225 - CEP 22453-900, Rio de Janeiro, RJ, Brazil. Email: tdiana.vanaduardmacedosoares@gmail.com. Website: www.strategy-research.com.
} 
seeks to fill this gap by proposing the Global Strategic Network Analysis - SNA - framework. Its purpose is to help firms that compete globally in alliances and networks to carry out their strategic assessments and decision-making with a view to ensuring dynamic strategic fit from both a global and relational perspective.

Assegurando adequação estratégica de empresas que competem globalmente em alianças e redes: propondo o Arcabouço Global SNA (Strategic Network Analysis)

Com vistas a sustentar sua vantagem competitiva no contexto de globalização e mudanças crescentes, mais e mais empresas estão competindo globalmente por meio de alianças e redes que as obrigam de adotar novos paradigmas e ferramentas gerenciais. No entanto, suas análises estratégicas raramente levam em conta as implicações estratégicas dessas alianças e redes, considerando suas características globais e relacionais, aparentemente, por falta de ferramentas analíticas adequadas. Este artigo contribui para as pesquisas que buscam preencher esta lacuna, ao propor o "Global Strategic Network Analysis — SNA — framework". O objetivo deste é de auxiliar empresas que competem globalmente em alianças e redes na condução das suas avaliações estratégicas e tomadas de decisão com vistas a assegurar uma adequação estratégica dinâmica pela perspectiva ao mesmo tempo global e relacional.

\section{Introduction}

The increasing globalization of markets and industries has radically changed firms' competitive conditions. It has stepped up foreign competition and the number of relationships between firms in different nations (Wiersema and Bowen, 2008), forming international and global networks of strategic linkages. Note that networks of linkages are henceforth called simply networks. By linkages, we mean alliances, mergers and acquisitions, agreements and contracts (Nohria and Garcia-Pont, 1991).

Consequently, firms have been obliged to adopt new paradigms and analytical tools for their strategic management. Indeed, to ensure sustainable success in this context, firms in alliances and networks must consider, not just strategic relational implications, i.e. those pertinent to their alliances and networks, in their strategic analyses, but also global relational ones.

However, leading firms rarely consider strategic relational implications, let alone global relational ones, admittedly, in many cases, due to a lack of adequate and user-friendly analytical tools and managerial processes (Pesquisa da PUC..., 2002; Tavares and Macedo-Soares, 2003). In this connection, it is relevant that Goerzen (2005) observed that the concept of alliance network management was only recently being viewed as an im- 
portant element of corporate strategy by the international firms' executives interviewed in his study, who admitted that their firms had not yet devised formal organizational rules and best practices to manage their alliance networks. Also, in a survey of 76 companies, Kale and Singh (2009) found that only $30 \%$ managed and regarded alliances as a portfolio (or network) when building their alliance strategy.

Thus, also at issue here is the crucial problem of managing strategic alliances and networks effectively. As Kale and Singh (2009) observed firms, on the one hand, are investing more and more in alliances and there is evidence that these indeed contribute to strengthening firms' competitive position. On the other hand, however, studies have revealed that in many cases alliances between firms have failed. As they put it (Kale and Singh, 2009:45):

Studies have shown that between $30 \%$ and $70 \%$ of alliances fail; in other words, they neither meet the goals of their parent companies nor deliver on the operational or strategic benefits they purport to provide (Bamford, Gomes-Casseres and Robinson, 2004). Alliance termination rates are reportedly over $50 \%$ (Lunnan and Hauglang, 2008), and in many cases forming such relationships has resulted in shareholder value destruction for the companies that engage in them (Kale, Dyer and Singh, 2002).

Note that with respect to the failure of international alliances and other linkages, Stonehouse at al. (2005) mention a rate of 20 to 50\%.

As Kale \& Singh (2007) observed, alliances are difficult to manage. By emphasizing the importance for alliance success of developing alliance management capabilities, they suggest that alliance failure is due to alliance management deficiencies.

In fact, in strategy research, only relatively recently - since the 1990s - has the importance of carrying out strategic analyses from a relational network perspective, i.e. pertinent to relationships or linkages and the networks formed by them, been recognized (Dyer and Singh, 1998; Hoffmann, 2007) and various relational network characteristics of strategic significance identified (Anand and Khanna, 2000; Baum, Calabrese e Silverman, 2000; Dyer and Nobeoka, 2000; Galaskiewicz and Zaheer, 1999; Gulati, Nohria and Zaheer, 2000; Koka and Prescott, 2008; Ozcan and Eisenhardt, 2009; Rowley, Behrens and Krackhardt, 2000).

As to strategy research on globalization and on international and global alliances and other linkages such as mergers and acquisitions - M \& A the number of investigations has increased significantly over the last decade 
(Garcia-Canal et al., 2002; Stonehouse et al., 2005; Wiersema and Bowen, 2008), and the importance of adopting a network perspective has been stressed in the international business literature (Coviello, 2006; Garcia-Pont and Nohria, 2002; Goerzen, 2005; Johanson and Vahlne, 2003 2009; Lazzarini, 2007; 2008; Vapola, Paukku and Gabrielsson, 2010). For a summary of the literature regarding network approaches to internationalization, see Loane and Bell (2006). See also Buckley and Casson's (2009) review of the progress of international business research over the last 30 years.

In this connection, it is noteworthy that the important themes for future research on international business identified in the literature by Griffith, Cavusgil and $\mathrm{Xu}$ (2008) included alliances and other linkages from a network perspective and globalization and issues related to the management of firms that operate globally.

It is moreover significant that, in 2011, the Strategic Management Society will be launching the Global Strategy Journal, specially oriented towards global strategy, with 10 themes, one of which is Global Strategy and Inter-Organizational Networks.

This paper purports to contribute to the above-mentioned investigations by proposing the Global SNA (Strategic Network Analysis) framework. The latter's aim is to help firms that compete globally in alliances and networks to carry out their strategic analyses and planning, with a view to ensuring dynamic strategic fit, from both a global and relational network perspective. When we use the expression "firms that... compete globally", we refer to both "global" and "transnational" firms in accordance with Bartlett and Ghoshal's $(1989,1998)$ and Harzing's (2000) typologies for multinational companies - MNCs.

The Global SNA framework is both a variation and an evolution of the generic SNA framework (Macedo-Soares, 2002; Macedo-Soares and Tauhata, 2002), and its other variations (Bastos and Macedo-Soares, 2007; Leite and Macedo-Soares, 2005; Macedo-Soares, Tauhata and Freitas, 2004; MacedoSoares, Tauhata and Lima, 2005; Macedo-Soares and Figueira, 2007; Macedo-Soares and Schubsky, 2010; Macedo-Soares and Mendonça, 2010), in that it considers the global together with the network perspective. The point is to take into account all the strategically significant factors - relational, non-relational, global and global relational - for accurate decision-making, in the case of firms that compete globally in alliances and networks. By framework we mean the conjunction of necessary analytical methodology, constructs, and model for carrying out strategic analyses. 
With respect to the relevance of the proposed analytical framework, it is noteworthy that methodological questions were highlighted among those identified by Griffith, Cavusgil and Xu (2008) as important for future investigations, especially the operationalization of key constructs for research into international business today, such as global strategy.

The remainder of this article is divided into the following five parts: research methods; results of the literature review; theoretical positioning; introducing the Global SNA framework; discussion and concluding remarks.

\section{Research methods}

Regarding the development of the Global SNA framework, it is significant that its current design evolved from two other main frameworks.

The first one, called the Generic Integrative - GI - framework was designed to help managers assess the adequateness of their firm's strategy, i.e. its strategic fit, by performing a comprehensive analysis of critical internal organizational variables in interaction with important macro-environmental and structural ones. The point was to identify the changes needed to improve strategic fit or to formulate a new adequate strategy and thus contribute to more effective strategic management. It built on the premises of the sociotechnical school (Cherns, 1976). Its original version was the result of a synthesis of theoretical constructs identified in the literature with inputs from primary sources, such as case studies and surveys (Macedo-Soares and Lucas, 1996). It was first tested in two multinationals (Macedo-Soares and Chamone, 1994). As the research progressed it incorporated some of Austin's (1990), Brandenburger and Nalebuff's (1997), Porter's (1980), and resource-based view (Wernerfelt, 1984; Rumelt, Schendel and Teece, 1991) constructs. Its more elaborate version was effectively applied to over 50 firms (e.g. MacedoSoares et al., 2005).

The second framework was called the Strategy Network Analysis - SNA framework which evolved from the GI one by incorporating relevant network constructs. It has already been applied to over 20 firms in different sectors (e.g. Macedo-Soares, Tauhata and Freitas, 2004). Because one of the main objectives of applying the framework in different firms was to contribute to theory development, this was performed through case studies, as recommended by Eisenhardt (1989) and Eisenhardt and Graebner (2007). In keeping with these authors, theory was developed through pattern recognition building on the constructs identified in the literature. 
Following the triangulation principle advocated by Yin (1994) for case studies, the necessary data for pattern recognition was collected from various sources, so as to ensure their consistency, using different means to mitigate the limitations inherent to each one. Generally three means were used: structured (Likert format) questionnaires based on the constructs from the framework's reference lists; interviews; documental/telematic investigations. The case studies illustrated the framework's application while providing inputs for validating and refining existing constructs as well as capturing elements that justified including new ones, thus contributing to theory building.

In the case of the generic SNA framework, the importance of carrying out strategic analyses from a relational network perspective was made evident by following the steps of the SNA methodology and comparing the results of the analysis of the strategic implications of non-relational factors with those pertinent to relational ones. As the case studies eloquently showed, two different pictures emerged from this comparison. By the same token, it became evident that by contemplating both relational and nonrelational factors, managers of firms in alliances and networks would have a more complete and accurate picture upon which to base their strategic planning and decision-making.

The Global SNA framework maintains the original design of the generic SNA framework, while adapting many of the latter's constructs and including new ones pertinent to global strategic management and global alliances and networks. It differs from the generic one in that it was developed for the specific case of firms that compete globally in alliances and networks. The new constructs were selected on the basis of their potential for providing appropriate measures to capture the necessary data for strategic fit assessments from a global relational network perspective.

The literature reviews that were undertaken to identify the necessary constructs for the frameworks' development followed the three-stage method recommended by Villas, Macedo-Soares and Russo (2008), which emphasizes the use of multiple rankings in the literature selection process. In the case of the Global SNA framework, the study adopted the rankings of the Institute for Scientific Information (ISI) and the Qualis (Capes, Brazil). Although a 10year time-frame was chosen for the review, seminal texts as well as books and theses on global strategic management and global alliances were also considered. 


\section{Results of the literature review}

In the initial literature review that provided the theoretical underpinning for the generic SNA framework, the studies identified as relevant for this purpose were found to have been strongly influenced by the social network literature (e.g. Granovetter, 1973).

Dyer and Singh (1998) and Gulati, Nohria and Zaheer (2000) were considered to be especially important in that they emphasize the "relational" view of strategic management, "which expands the unit of analysis from an individual firm or a single dyadic relationship to include the focal firm and all its interorganizational relationships" (Hoffmann, 2007:829).

As to relational constructs and indicators for analyzing the strategic implications of alliances and other linkages from a network perspective using the generic SNA framework, Galaskiewicz and Zaheer (1999), Gulati, Nohria and Zaheer (2000), Kale, Singh and Perlmutter (2000) and Knoke (2001) provided the greatest contributions.

Galaskiewicz and Zaheer presented three key dimensions - network structure, network composition and network modalities - and several characteristics for analyzing the impact of networks at the corporate level by exploring some of the conditions for robust competitive advantage using each dimension.

Basing themselves on empirical investigations of several other scholars in this field, Gulati, Nohria and Zaheer (2000) provided additional characteristics for the dimensions at issue and showed how they have strategic implications, creating opportunities and threats at industry level, and strengths and weaknesses at corporate level. They also implicitly suggested that network management could be considered another key dimension, at the corporate level. Partner fit (strategic, cultural and organizational), especially in terms of compatibility and complementarity, was identified as a highly relevant construct in this dimension. They also stressed the dynamic nature of most networks, especially in the current context of constant change, showing just how crucial it is to view strategic fit, in terms of what Zajac, Kraatz and Bresser (2000) called "dynamic" fit, when adopting a relational perspective.

For operationalizing strategic network analysis, Knoke's (2001) concept of egocentric network inspired the concept of firm 'ego net': network formed by the focal firm and its main strategic partners and relationships within the context of its value net. Brandenburger and Nalebuff (1997) define the latter as a network that includes all strategic actors - both partners and non 
partners - in its competitive arena, and their interdependencies, that contribute to capturing and creating value that is significant for the competitive advantage of the focal firm.

Where relational analytical frameworks were concerned, only a few proposals were found in the literature, notably those developed by Contractor, Wasserman and Faust (2006), Gnyawali and Madhavan (2001), Madhavan, Koka and Prescott (1998) and McEvily and Zaheer (1999).

In spite of the unquestionable contribution of these frameworks to strategy network research, they were deemed too complex, theoretical and focused on specific aspects of networks. Moreover, they did not take into consideration both perspectives - relational and traditional (non-relational). In other words, they did not contemplate organizational, structural, macro-environmental, and relational factors together within a systemic, integrative and dynamic approach as was the objective of the generic SNA framework.

Although the focus here is on the global dimension of alliances and networks, and therefore it is not deemed necessary to present a review of all the more recent works identified in the literature on alliances and networks that do not have this focus, a few that are pertinent to our proposal should be mentioned.

According to Ozcan and Eisenhardt (2009), there has recently been a greater variety of investigations on 'portfolios' of alliances. Considering the network dimension of our proposal it is relevant that these authors define portfolio as the set of direct ties (or linkages) of a focal firm (Das and Teng, 2002), observing that it can also be considered an egocentric network.

Ozcan and Eisenhardt (2009:246) investigated how firms can develop "high-performing portfolios". They present evidence derived from six case studies of entrepreneurial rivals in the wireless gaming industry, which suggests that executives are more likely to develop such portfolios "when they visualize (them) in the context of the entire industry as opposed to a series of single ties" and when ties are formed simultaneously with multiple partners. They propose a theoretical framework that "emphasizes agency and strategic action in contrast to a deterministic account of dyadic interdependence and social embeddedness" (Ozcan and Eisenhardt, 2009:246). Their view confirms the importance of taking a broader strategic approach, when analyzing a firm's network of alliances; an approach that includes structural industry and macroenvironmental factors together with the relational ones. 
Hoffmann (2007) draws attention to the fact that the firm has to know how to configure its portfolio of alliances, whose management should be goal-oriented. Based on a study of the evolution of alliance portfolios in a given business unit, he identifies 3 distinctive portfolio strategies "that allow firms to cope with a complex and changing environment": i) shaping strategy - actively shaping the environmental development, according to firm strategy, by expanding and deepening the company's resource endowment in a focused manner - supported by core exploration alliances; ii) adapting strategy - reactively adapting to the environment's dynamics "to increase strategic flexibility by broadening the company's resource endowment and generally improving the ability to learn and change" supported by probing or platform alliances; iii) stabilizing strategy to avoid organizational change - "efficiently exploiting the existing resources and protecting competitive advantages as much as possible" - supported by exploitation alliances to commercialize resources and capabilities acquired through exploration (Hoffmann, 2007:830-831). This classification of strategies and respective alliances is relevant to our proposal in that it was found to be useful for the analyses of portfolio management of strategic alliances from an international perspective (Vapola et al. 2010).

With regard to alliance portfolios, we should also mention Lavie's (2007) empirical investigation of software firms and their alliances, whose results suggested that network resources' contribution to firm value creation varies according to resource complementarity. The investigation also made evident how the intensity of competition among partners in the firm's alliance portfolio can improve its market performance and how the partners' relative bargaining power in the portfolio can affect the firm's capacity to appropriate network resources. This is significant in that it refers to a key construct of the 'network membership' dimension in the SNA framework which we believe could be of special importance in the case of firms that compete globally: global focal firm's and global partners' access to global network resources (see table 1, items 2.6 and 2.7).

Kale and Singh (2009:52) argue that firms in alliances should not only have what they call a dedicated alliance function. They should also develop capabilities to manage alliance portfolios, which could be used for the "effective management of other interfirm relationships, including acquisitions". Another success factor highlighted by these authors is the construction of portfolio alliance governance, especially during the alliance life-cycle's design phase. This was found to be all the more important given that the "use 
of (network) governance mechanisms" was already a key construct of the generic SNA framework.

In fact the literature review update revealed several authors who investigated alliance governance mechanisms, or so-called relational governance mechanisms, both formal and informal (Gulati and Nickerson, 2008; Hoetker and Mellewigt, 2009; Mitsuhashi, Shane and Sine, 2008; Nielsen, 2009; Purunam and Vanneste, 2009; Teng and Das, 2008; Wang, He and Mahoney, 2009; Yang, Lin and Lin, 2010). Provan and Kenis (2007) highlighted the fact that different forms of network governance can constitute either strengths or weaknesses depending on structural factors and relational contingencies, such as trust, size, goal consensus and task nature.

In keeping with our proposal's global perspective, we now present the results of the literature review update that are specific to this perspective.

In the course of this review, it became evident that we first of all needed to understand what exactly is meant by globalization. Indeed, generally, globalization refers to a process "implying that countries over time become more similar to each other in terms of culture and institutional settings" (Johanson and Vahlne, 2003:98). On the other hand, Ghemawat observes that today one cannot as yet speak of globalization; it is necessary to think strategically in the context of "semi-globalization" (Ghemawat, 2007:10). However, from a process viewpoint, semi-globalization can be considered part of the globalization process, and as Buckley and Ghauri argue globalization "is proceeding at a differential pace in different types of markets" (Buckley and Ghauri, 2004:82).

It is important to note, moreover, that globalization can be of economies, markets, industries and strategies (Stonehouse et al., 2005).

Where globalization of markets is concerned Buckley and Ghauri observe that this process is a deliberate one - "markets are globalized by the actions of MNEs" (Buckley and Ghauri, 2004:82) - whose main drivers are multinationals' localization and ownership strategies. Their view differs from that put forward by Vapola et al. (2010) who found that a multinational's strategy can be driven by either the focal multinational or its partners.

As to globalization of strategy, Stonehouse et al. (2005) define it as

[...] the extent to which an international business configures and co-ordinates its strategy globally. A global strategy will normally include a global brand name and products, presence in major markets throughout the world, produc- 
tive activities located so as to gain maximum advantage, and co-ordination of strategy and activities throughout the world" (Stonehouse et al., 2005:5).

With respect to the difference between global and international business they state that the latter "simply implies that an organization is operating in more than one country, or [...] organizations from different countries are trading across their national boundaries" (Stonehouse et al., 2005:4).

To distinguish between different international businesses, a classic reference is Bartlett and Ghoshal's (1989; 1998) typology of MNCs. Harzing (2000) confirmed the latter's validity empirically through her study of 37 MNCs in 9 different countries and 166 subsidiaries. The three basic types of MNCs were identified: Multi-domestic, Global and Transnational. In line with Bartlett and Ghoshal $(1989,1998)$, the strategic orientation of Multi-domestic firms was defined as responding to national differences, that of Global firms as "building cost advantages through realization of economies of scale (Bartlett and Ghoshal, apud Harzing, 2000:107), and that of Transnational ones as coping with both demands at the same time. Harzing (2000:108) notes that "competition takes place at a global level for both Global and Transnational companies". This is why we consider both Global and Transnational companies as firms that compete globally.

Harzing also proposed an extension to this typology. Using Prahalad and Doz's (1987) integration/responsiveness - I-R framework, her study found that for each type of MNC the subsidiaries differed in terms of interdependence and local responsiveness. She thus verified that while Multi-domestic companies combine low integration and high responsiveness, Global ones combine high integration with low responsiveness and Transnational firms display both high integration and high responsiveness.

Similarly to Bartlett and Ghoshal (1989; 1998) and Harzing (2000), Hitt, Ireland and Hoskisson (2009) distinguish between Multi-Domestic, Global and Transnational strategies. They define the multi-domestic strategy as "an international strategy in which strategic and operating decisions are decentralized to the strategic business unit in each country so as to allow that unit to tailor products to the local market" (Hitt, Ireland and Hoskisson, 2009:220). The global one is considered to be "an international strategy through which the firm offers standardized products across country markets with competitive strategy being dictated by the home office" (Hitt, Ireland and Hoskisson, 2009:221), and the Transnational strategy is "an international strategy through which the firm seeks to achieve both global efficiency and local responsiveness" (Hitt, Ireland and Hoskisson, 2009:222). They note that 
the latter is "becoming increasingly necessary to compete in international markets" and therefore more and more firms are using a transnational strategy (Hitt, Ireland and Hoskisson, 2009:222).

Hitt, Ireland and Hoskisson (2009) also list different forms of entry into the international market - export, licensing, alliances, acquisitions and creation of new subsidiaries - , highlighting alliances and acquisitions as the ones most adopted in the current global scenario. Drawing on Nippa, Beechler and Klossek (2007), they observe that, recently, strategic alliances have become a "popular means of international expansion" (Nippa, Beechler and Klossek, 2007:226), because they enable firms to share the risks and resources needed for entering into foreign markets. They can also help develop new core competencies for ensuring the firm's future competitiveness (Hitt et al., 2004).

With respect to acquisitions, Hitt, Ireland and Hoskisson (2009:227) explicitly say that: "...acquisitions often provide the fastest and the largest initial international expansion of any of the alternatives" (reference is made to Hitt and Pisano, 2003).

Regarding the firm's internationalization process, Dunning and Lundan (2008:212-231) consider a series of phases, the last one of which could be considered that of competing globally: 1) "Exports and Foreign Sourcing"; 2) "Investment in Marketing and Distribution"; 3) "Foreign Production of Intermediate Goods and Services"; 4) "Deepening and Widening of the Value-added Network", where foreign affiliates of multinationals control most stages of the value chain, but generally rely on R \& D carried out in the home country; 5) "The Integrated Network Multinational", that is characterized by a distribution of value-added activities between the home and foreign countries. "In this phase, the parent and the foreign affiliate produce different products, each of which is sold in world or regional markets. Part of the $R \& D$ for each product is also undertaken at the location of the subsequent stages of production (Dunning and Lundan, 2008:228)." An important component of this phase is "strategic asset-seeking investment, which may take the form of both joint ventures and M\&As. The authors observe, however, that the increasing complexity and new organizational configurations of international companies, such as "born globals" etc., have resulted in "phase jumping" (Dunning and Lundan, 2008:231): “...globally oriented MNEs are increasingly adopting a pluralistic and integrated approach to their modalities of entering new markets, or responding to changes in the global economic environment" (Dunning and Lundan, 2008:215).

Particularly relevant to our proposal here are Dunning and Lundan's (2008) arguments in favor of the network approach when analyzing MNCs 
and their web of cooperative agreements, considering the systemic and structural changes these have undergone with globalization.

In the literature on globalization, as we saw above, alliances and other linkages, namely M\&As, are stressed as key internationalization options in the current globalized context.

According to Doz and Hamel (1998), strategic alliances have become essential in the new competitive environment shaped by the globalization of the economy, the information age and the structural changes in existing markets and industries, or what they call the "race for the future among the world's fleetest competitors" (Doz and Hamel, 1998:2).

In this race, according to these authors, alliances have at least the three following purposes (Doz and Hamel, 1998:4-5): 1. Co-option — transformation of potential rivals into allies and providers of the complementary goods/services for developing new businesses; 2) Co-specialization - partners with unique and differentiated resources contribute to synergistic value creation; 3) Learning and Internalization - new skills (especially tacit skills) can be learnt through the alliance, and this learning can be used also for other activities.

Lasserre (2003), who stresses the essential role of alliances in the current globalization context, presents Doz and Hamel's three main purposes for alliances as three different types of global strategic alliances: coalitions, co-specializations, and learning alliances. He proposes a typology of international alliances, according to their geographic scope (global or local) and their object (market access or capabilities enhancing). In a local alliance - foreign investor with a local firm - the foreign company seeks to enter a local market ("alliance for market entry", e.g. traditional joint ventures in emerging markets) or to have access to resources available in a particular country ("resource-based country alliance", e.g. joint ventures in resource-rich countries). In a global alliance the company seeks to develop a global market presence through the alliance ("global reach alliance") or to leverage the worldwide competitive capabilities of the firms in the alliance ("global leverage alliance" (Lasserre, 2003:99), e.g. R\&D partnerships, coproduction alliances.

Similarly to most other researchers, García-Canal et al. (2002) viewed global alliances as a means to accelerate firms' international expansion, because they not only provide access to several new markets, but also boost their international competitiveness by using their partners' resources, even if they pose many challenges due to their complexity and need for high partner 
flexibility. They proposed a typology of cooperative strategies where international alliances were distinguished according to scope (local and global) and orientation. Where scope was concerned, they meant "not only the number of countries in which the partners agree to perform joint activities ..., but also those which are affected by the coordination of the international activities and strategies of the partners" (García-Canal et al., 2002:94).

This typology, based on 11 case studies of multinational Spanish firms, contemplates the alliance's orientation in terms of "exploitation" - (MNC exploits its proprietary assets in the foreign market through local or global partners) and "exploration" (MNC explores new ways of improving its competencies). Garcia-Canal et al. thus identified the four strategies listed below. In their research Strategies II, III and IV all referred to global alliances, but only Strategy IV had an exploration orientation.

Strategy I - Local alliances, i.e. alliances with local partners to enter into specific markets. From the MNC viewpoint, these have above all an exploitation orientation, i.e. to exploit its proprietary assets in the foreign market by way of a local partner;

Strategy II — One key global alliance for market access - implying a close coordination of all international alliances and activities;

Strategy III - Multiple regional-scope alliances for market access - multi-country alliances through multiple, independent alliances;

Strategy IV - Competence-building alliances for access to partner's resources in order to compete with international rivals.

With respect to alliance orientation in terms of the exploitation and exploration framework, as Lavie and Rosenkopf (2006:798) observed, the latter was first applied in the inter-organizational context by Koza and Lewin (1998) "who note that firms may form alliances to exploit existing knowledge or to explore new opportunities." Lavie and Rosenkopf (2006) propose 3 separate domains of exploration/exploitation to describe an alliance: 1) function of the alliance in the value chain, whether knowledge generating (e.g. R\&D alliance) - exploration, or knowledge leveraging (e.g. marketing/production alliance) - exploitation; structure - alliance with new partner - exploration, or former partner (recurrent alliance) - exploitation; attribute - partner profile in terms of having different attributes (exploration) or similar ones (exploitation) to those of prior partners.

As to networks, as we saw above, the firm's internationalization process has increasingly been viewed in the context of its networks of linkages, rather than as a lone action. 
Basing themselves on an extensive review of the international business literature, Johanson and Vahlne $(2003,2009)$ observe that many studies in this field, emphasize the need to develop new models from a network perspective, in order to provide a better explanation of firms' rapid internationalization (Johanson and Vahlne, 2003, see references to Oviatt and McDougall, 1994; Bell, 1995; Coviello and Munro, 1997; Chetty and Blankenburg Holm, 2000). They propose the business network model which is a synthesis of their earlier behavioral model, called the Uppsala or $U$ Model, (Johanson and Vahlne, 1977), and inputs from recent research into business networks.

Johanson and Vahle's new model $(2003,2009)$ combines the experiential learning-commitment mechanism of the U Model with a similar one focused on business network relationships. Relationships are viewed as offering "potential for learning and for building trust and commitment, both of which are preconditions for internationalization."( Johanson and Vahle, 2009:1412). Relationships should thus enable firms to enter new country markets where they can develop new relationships which become a platform to enter even more country markets.

Loane and Bell's (2006) empirical research into networks of internationalizing firms in Australia, Canada, Ireland and New Zealand, made evident the importance of not just leveraging the resources of the existing network, but especially of developing new networks to accelerate the internationalization process of entrepreneurial firms. They highlight the role of personal ties, notably "weak" ones (e.g. acquaintances) versus "strong" ones (e.g. family) at the beginning of this process, because they provide a greater diversity of knowledge. Their research suggests that such processes established on the basis of experience in different markets contribute to developing international networks during their initial stages.

Investigating global firms in the automobile industry from the network perspective, Garcia-Pont and Nohria (2002) identified density of ties between members of the same strategic group as a critical factor for alliance formation in a strategic group. They thus verified that local mimetism — "firms mimic the behavior of those they view as strategically similar or as belonging to the same strategic group" (p. 308), rather than industry-wide or global mimetism, was the major driver of network formation in an industry.

Regarding global alliances from a network perspective, a significant contribution to the literature was made by Lazzarini $(2007,2008)$. Focusing on the global airline industry, he investigated how networks of informal ties 
evolve towards formal networks of multilateral alliances (e.g. Star Alliance), according to their structural characteristics - density and centrality - and resource profile (diversity), and the latter's implications for firm performance. He adopts the term "constellation" for multiple partner alliances, a concept originally proposed by Gomes-Casseres $(1994,1996)$, to refer to networks of alliances between multiple rival partners that form the basis of new units of competition.

Lazzarini (2007) has also contributed to demarking the boundaries of constellations, showing that distinct patterns of membership - configuring explicit or implicit constellations - have different implications for firm performance.

As to network management, special mention should be made of the following two authors: Goerzen (2005) and Vapola et al. (2010).

Goerzen (2005) highlights the importance of alliance network management for network performance basing himself on a study of multinationals, many of which can be considered global firms. In this study he identifies the three basic categories of strategic intent in terms of value creation through alliance network management: i) reduction of organizational costs; ii) enhancement of competitive position; iii) improvement of knowledge acquisition. His contribution lies in defining organizational structures and management processes for each category (in Goerzen, 2005, see Table 3, p. 99).

Drawing on the I-R framework (Prahalad and Doz, 1987), Vapola et al. (2010) show how and why global alliance portfolio management differs according to the MNCs international strategy and how the needs for local responsiveness or global integration influence the choice of partners and the level of partner integration. The MNC's local responsiveness was found to have an impact through partner heterogeneity and the MNC integration through global partner integration. Thus a global strategy favoring global integration would have a high level of partner integration, while a transnational strategy that favors both local responsiveness and global integration would imply both high partner heterogeneity and integration.

Vapola et al. further contribute by showing how the I-R framework and its constructs for analyzing the organizational characteristics of the MNC's network of subsidiaries can be used to analyze the organizational characteristics of the wider network of global alliances, according to its strategic orientation. These constructs are: configuration of assets and capabilities across the network; role of overseas partners; development and diffusion of knowledge (throughout the network); management mentality towards its (foreign) partners; operational control; structure of network with (foreign) partners. 
In sum, there has been a significant increase in the number of investigations into alliances and networks in business strategy from a global perspective.

Yet, to date, we have not found strategic assessment tools similar to our proposal of a Global SNA framework, i. e. that aims at helping managers assess and ensure the strategic dynamic fit of firms that compete globally through an analysis that contemplates the strategic implications of global relational factors, together with non-relational global ones within an integrative dynamic network perspective. This proposal has the advantage of being consistent with the classic and friendly SWOT (strengths, weaknesses, opportunities and threats) paradigm that is widely used by practitioners in firms worldwide, which is not the case of the relational frameworks identified in the literature.

\section{Theoretical positioning}

Before introducing the Global SNA framework, we present the definitions adopted for its central concepts, the key typologies used, and the main assumptions underlying our proposal.

\section{Definitions, typologies and assumptions}

To define the concepts of, respectively, global and transnational strategy, we draw on Hitt, Ireland and Hoskisson (2009), Lasserre (2003) and Stonehouse et al. (2005), as follows:

A global strategy is a strategy that the firm adopts with a view to competing in key markets in the world with standardized products, services and solutions, and that implies co-ordination of strategy, dictated by the head office, and of activities located throughout the world so as to gain maximum advantage.

A transnational strategy is a strategy that the firm adopts with a view to competing in key markets in the world with differentiated and specialized products, services and solutions that are customized to meet local market requirements, and that implies both global efficiency and flexible coordination through an integrated network of partners, customers and suppliers.

We adopt here the typologies of Bartlett and Ghoshal $(1989,1998)$ Harzing (2000), and Hitt, Ireland and Hoskisson (2009) to distinguish between Multi-domestic, Global and Transnational strategies. In accordance with Har- 
zing (2000), that extends this typology using Prahalad and Doz's (1987) I-R framework, we further characterize a global strategy as combining high integration with low responsiveness, and a transnational one as displaying both high global integration and efficiency and high local responsiveness.

To identify the global firm's market strategy, we use Mintzberg's (1995) typology - differentiation (in terms of price, image, support, quality and design), non-differentiation, and scope (broad/narrow), as we did in the case of the generic SNA framework.

To further characterize the global or transnational strategy's content, we draw on Fahey and Randall's (1998) constructs: scope - product/service, customer, geographic (location - choice of countries - key, emerging, platform etc.), vertical and stakeholder, competitive differentiation or posture - product features emphasized, types of functionality provided, appropriate price structures - and goals in accordance with an explicit/implicit "vision", "mission", or "strategic intent". Inspired by Buckley and Ghauri (2004), we also consider the ownership structures of the firm's international operations.

As to Alliances, they are defined in accordance with Gulati (1998) as voluntary arrangements among two or more independent firms, involving exchange, sharing or joint development or provision of technologies, products or services.

As we have already noted, alliances are also considered a type of linkage, in keeping with Nohria and Garcia-Pont (1991). Drawing on the latter as well as Contractor and Lorange (1988), we adopt a typology of linkages that include alliances based on the degree of relationship intensity/interdependence. Linkages are thus classified running the following gamut from high to low ends: mergers \& acquisitions - M\&A, independent joint ventures, cross equity ownership, minority equity investment, joint Research and Development $-\mathrm{R}$ $\& \mathrm{D}$, production, or marketing, franchise alliances, know-how or patent licensing, agreements (marketing, manufacturing, supply, services, distribution). Apart from M\&A, the other linkages are considered to be alliances when they meet our definition of alliances based on Gulati (1998). Note that the linkages are considered strategic when they contribute directly to a firm's competitive advantage (Macedo-Soares, 2002).

For classifying alliances of global or transnational firms, we adopt Doz and Hamel's (1998) three basic categories that are also value propositions and that Lasserre (2003) considered to be alliance strategies: i) Coalition; ii) Cospecialization; iii) Learning. 
We also draw on Lasserre's (2003) typology of international/global alliances in terms of being a local alliance (alliance for market entry or resource-based country alliances) or global (global reach alliance or global leverage alliance), as well as Garcia-Canal et al.'s (2002) characterization of international/global alliances in terms of their scope and exploitation/exploration dimensions. For an in-depth analysis of these alliances according to the latter dimensions, we adopt the 3 domains of exploration and exploitation proposed by Lavie and Rosenkopf (2006): function, structure and attribute. We also consider characterizing the alliances according to Hoffmann's (2007) portfolio strategies.

As to the strategic network concept, we base ourselves on Gulati, Nohria and Zaheer (2000:203):

a firm's set of relationships, both horizontal and vertical, with other organizations - be they suppliers, customers, competitors, or other entities, - including relationships across industries and countries. (It is) composed of interorganizational ties that are enduring, [...] of strategic significance for the firms entering them, and include strategic alliances.

A fundamental assumption of the Global SNA framework, as well as the previous frameworks, is that strategic management, - the interacting and overlapping processes of strategy development, implementation and evaluation - implies a series of assessments (Van Der Heijden, 1996), in accordance with the principle of strategic fit: the importance for the strategy's effectiveness of ensuring consistency between all the strategically significant factors at play (Andrews, 1971; Fiegenbaum, Hart and Schendel, 1996; Hofer and Schendel, 1978; Siggelkow, 2001). As mentioned earlier, because of networks' dynamic nature and the current turbulent context, we are especially concerned with dynamic strategic fit (Zajac, Kraatz and Bresser, 2000). We contend that the latter implies almost perfect, but not perfect fit, what we called positive imperfect fit (Macedo-Soares, 2002), whose assessment requires taking into account both potential and real strategic implications, at corporate and industry levels.

Considering the increasing importance of the global and relational perspectives for effective global strategic management, it is contended, furthermore, that global relational variables should be included among the strategically significant factors, in the case of firms that operate globally in alliances and networks. By the same token, from these perspectives and in the case of this type of firm, 
dynamic strategic fit only exists, i.e. strategy can only be considered adequate when it capitalizes on the strengths constituted, not merely by the firm's internal (real and potential) resources and necessary organizational conditions to harness these, but also by the (real and potential) resources provided by the network of global relationships, reducing (real and potential) weaknesses pertinent to both the firm and this network. The aim is to exploit both global macro-environmental (real and potential) opportunities and those offered by the network, minimizing (real and potential) threats posed by both the global macro-environment and the network. (Adapted from Barney's (1997) concept of good strategy).

Another important assumption is that of the importance of conceptual tools, such as frameworks, for strategic assessments, given that inspiration and intuition are necessary but not sufficient for conducting the assessments in a systematic and comprehensive fashion.

As in the case of the generic SNA framework, the Global one contemplates the three key dimensions - network structure, network composition and network modalities — identified by Galaskiewicz \& Zaheer (1999) and elaborated upon by Gulati, Nohria and Zaheer (2000) for analyzing relational implications from a network perspective, at both corporate and industry levels. Likewise, the Global SNA framework includes the alliance/network management dimension proposed by Gulati, Nohria and Zaheer (2000) at corporate level.

\section{Introducing the Global SNA framework}

The Global SNA framework has three main components: 1. A methodology to conduct the global strategic network analysis; 2 . Reference lists to guide data collection; 3. A Global SNA model to help map the firm's global ego net within its global value net.

\subsection{The Global SNA Methodology}

We describe the Global SNA methodology's steps below.

1) Characterize the competitive and market strategy of the focal firm that competes globally, using the typologies and constructs adopted for this purpose: Bartlett and Ghoshal (1989, 1998); Buckley and Ghauri (2004); Harzing (2000); Hitt, Ireland and Hoskisson (2009); Lasserre (2003); Mintzberg (1995); Fahey and Randall (1998). 
2) Identify and analyze the strategic implications of the global political, economic, socio-cultural and demographic macro-environmental factors (Austin, 1990), as well as those of the key global strategic actors/roles - rival, client, supplier, new entrant, substitute (Porter, 1980) and complementor (Brandenburger and Nalebuff, 1997) of the focal firm's global value net, in terms of constituting real and potential opportunities and/or threats. Make use of generic reference lists of indicators of global macroenvironmental factors' and actors/roles' strategic implications, adapted to the industry focused on.

3) Identify and analyze the strategic implications of the organizational, technological, physical, financial, and human resources/competencies of the global firm, as well as that of the necessary organizational conditions to manage these, in terms of constituting real and potential strengths and weaknesses for implementing the global or transnational strategy, considering the latter' s characteristics. Make use of reference lists of necessary and desirable attributes of these resources and organizational conditions for implementing successfully such a strategy.

4) Identify and classify the strategic global alliances and other significant global linkages between partners that constitute the focal firm's global ego-net, according to the typologies adopted (Contractor and Lorange, 1988; Doz and Hamel, 1998; Garcia-Canal et al., 2002; Gulati, 1998; Hitt, Ireland and Hoskisson, 2009; Hoffmann, 2007; Lasserre, 2003; Lavie and Rosenkopf, 2006; Nohria and Garcia-Pont, 1991).

5) Start mapping the strategic linkages of the focal firm's global ego net within its global value net, with the help of the Global SNA model described in Section 5.3.

6) Identify the relational characteristics of the focal firm's global ego net, in terms of key network dimensions, making use of reference lists of global relational constructs (see table 1 in Section 5.2). Add relevant characteristics to the global ego net model. With the help of the listed indicators, analyze these characteristics' implications at industry and corporate levels, in terms of constituting respectively, (real and potential) opportunities and threats, strengths and weaknesses.

7) Capture data on the performance of the focal firm, in keeping with hard (quantitative) and soft (qualitative) measures and indicators in the following dimensions when applicable: financial (e.g. cash flow; ROI, EBITDA), operational, customer satisfaction, head office employee satisfaction, over- 
seas employees' satisfaction, global partners' satisfaction, social responsibility, environmental responsibility.

8) Assess all strategically significant factors and pose the following question: "Does the global or transnational strategy, given its characteristics, have the potential to capitalize on the strengths constituted, not merely by the firm's internal globally relevant (potential and real) resources and necessary organizational conditions to harness these, but also by the resources provided by the network of global relationships, reducing weaknesses (potential and real) pertinent to both the firm and the network, so as to exploit not only global macro-environmental opportunities (potential and real), but also those offered by the network, minimizing threats (potential and real) posed by both the global macro-environment and the network?"

9) Identify sources of inconsistencies. Verify whether they are due to a lack of essential resources/conditions for the firm's business on the global competitive scenario or if they stem from factors that may appear to be discrepant, at the time of the assessment, but that are critical for the future development of the necessary competencies for sustaining the firm's competitive advantage (Aaltonen, 2007). Instead of being viewed as a weakness, an inconsistency related to the latter type of factors should be considered as a significant potential strength in that it accounts for the positive imperfect fit that enables dynamic fit and thus agile strategies (Doz and Kosonen, 2008).

One more step is suggested when the assessments reveal inadequate fit.

10) On the basis of the assessment's results regarding the type of inconsistencies that account for weaknesses, consider changes in global and other organizational or relational features in order to enhance the firm's chances of ensuring dynamic strategic fit. Assess their impact in terms of challenging the firm's global or transnational strategy. Make strategic decisions - adjustments or adoption of a new strategy - taking into account all stakeholders involved, and the importance of sustaining superior performance as measured by both hard and soft indicators regarding the firm's potential to create future value in its global competitive context.

\subsection{Reference lists of global relational constructs}

In order to carry out the strategic analysis in keeping with the steps outlined above in the previous section, it is fundamental to have reference lists of the 
different categories of factors to be analyzed at each step. These lists indeed constitute the basis for designing tools, such as questionnaires for conducting surveys or for guiding documental investigations and interviews, through which the necessary data and information for carrying out the analysis are captured. They are also necessary as references in order to help interpret the data collected using these tools.

Thus, in the scope of the development of the Global SNA framework, new reference lists of the most relevant constructs of possible strategic implications of globally pertinent relational/network factors had to be created to facilitate strategic assessments from a global relational perspective. They were adapted to the case of global strategic network analysis from the original generic SNA reference lists, incorporating the new constructs identified in the literature pertinent to the new global perspective.

As these lists are meant to be self-contained, construct definitions are included, as well as references, when available, of empirical investigations that provided evidence concerning the relational characteristics' implications (in terms of strengths and weaknesses at corporate level, and opportunities and threats at industry level).

Table 1 is an abbreviated form of the reference lists for analyzing global relational factors (Step 6). The indicators for positive implications (strengths and opportunities) of relational factors are in bold type. Implications can sometimes be either negative or positive depending on the case. We use the term "tie" - synonym of linkage - in this table because it was the term used in the lists of the generic SNA framework, drawing on Gulati, Nohria and Zaheer (2000). When the term alliance portfolio is used it is because the author referenced uses this term. However, as already mentioned, it can be considered a synonym of network, precisely, 'egocentric alliance network' (Hoffmann, 2007:828). Note that some of the authors referenced in table 1 are not mentioned in our literature review; this is because they were already included in the generic SNA framework's reference lists.

It is important to clarify that as the proposal at issue here refers to work in progress, Table 1 includes several constructs and indicators that have not yet been tested. In many cases, especially with respect to global relational characteristics, we base ourselves on suppositions derived from exploratory investigations whose results have not yet been fully consolidated, where their global relational perspective is concerned. In these cases, we put the term 'global' in brackets. 


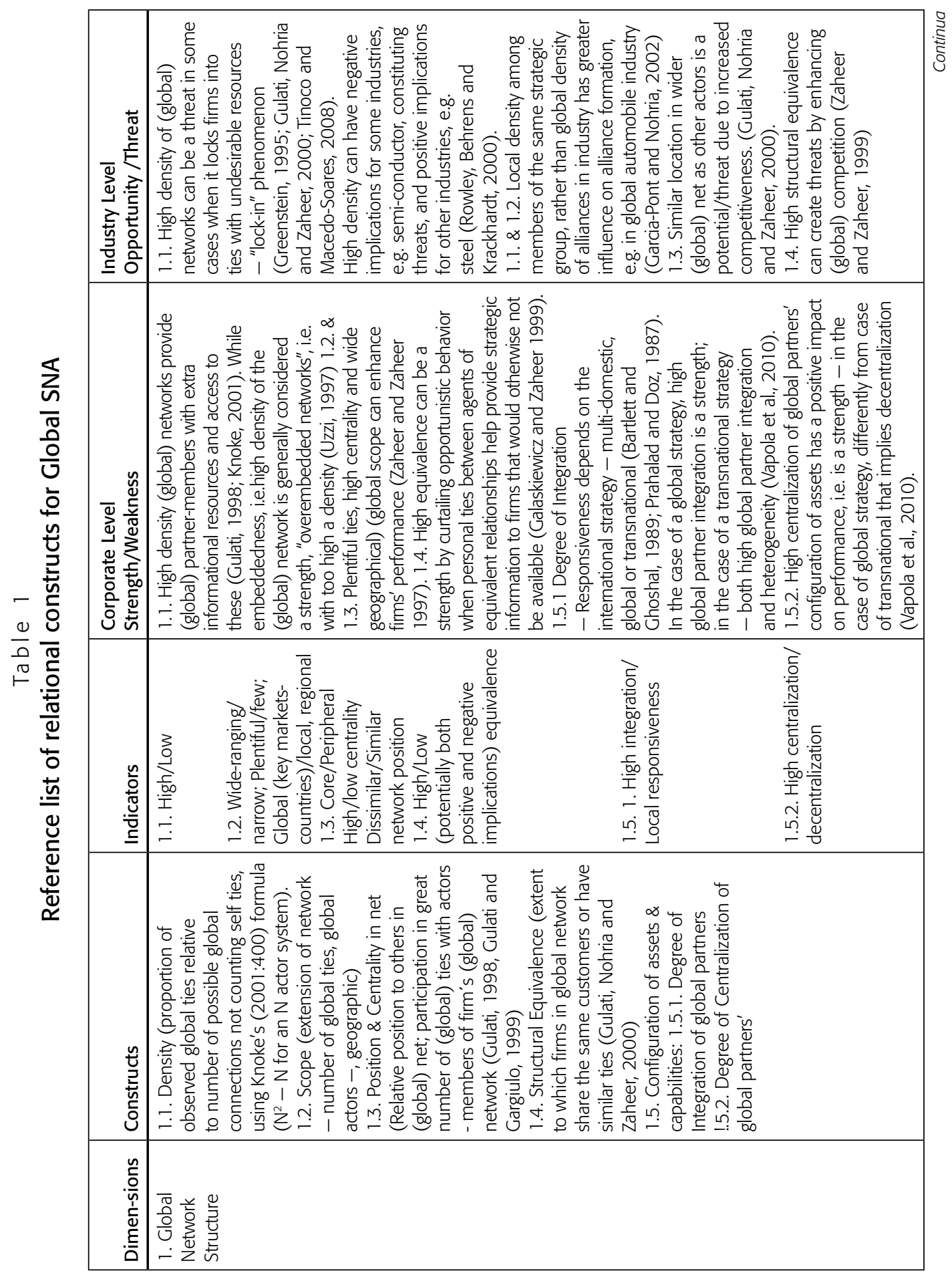




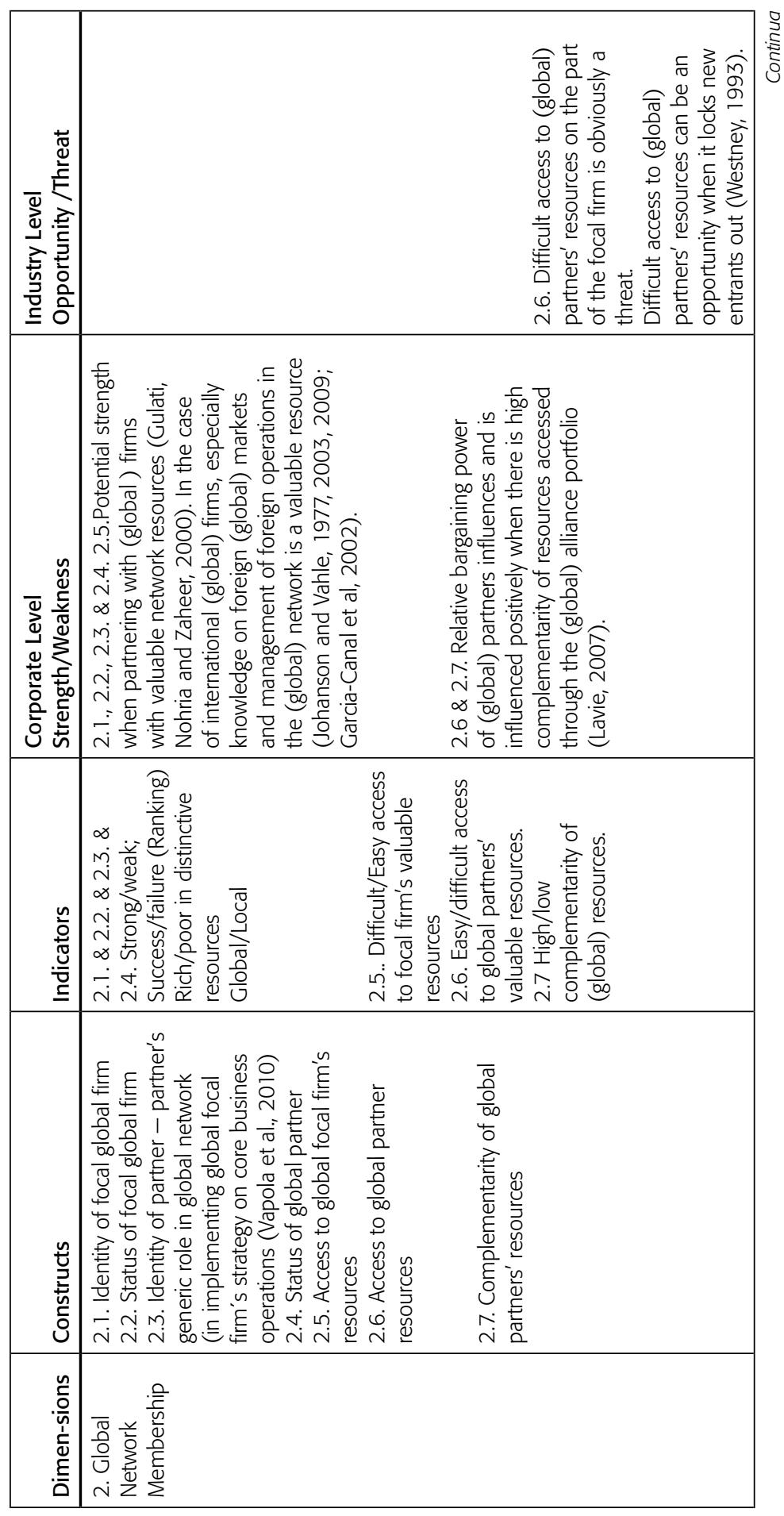




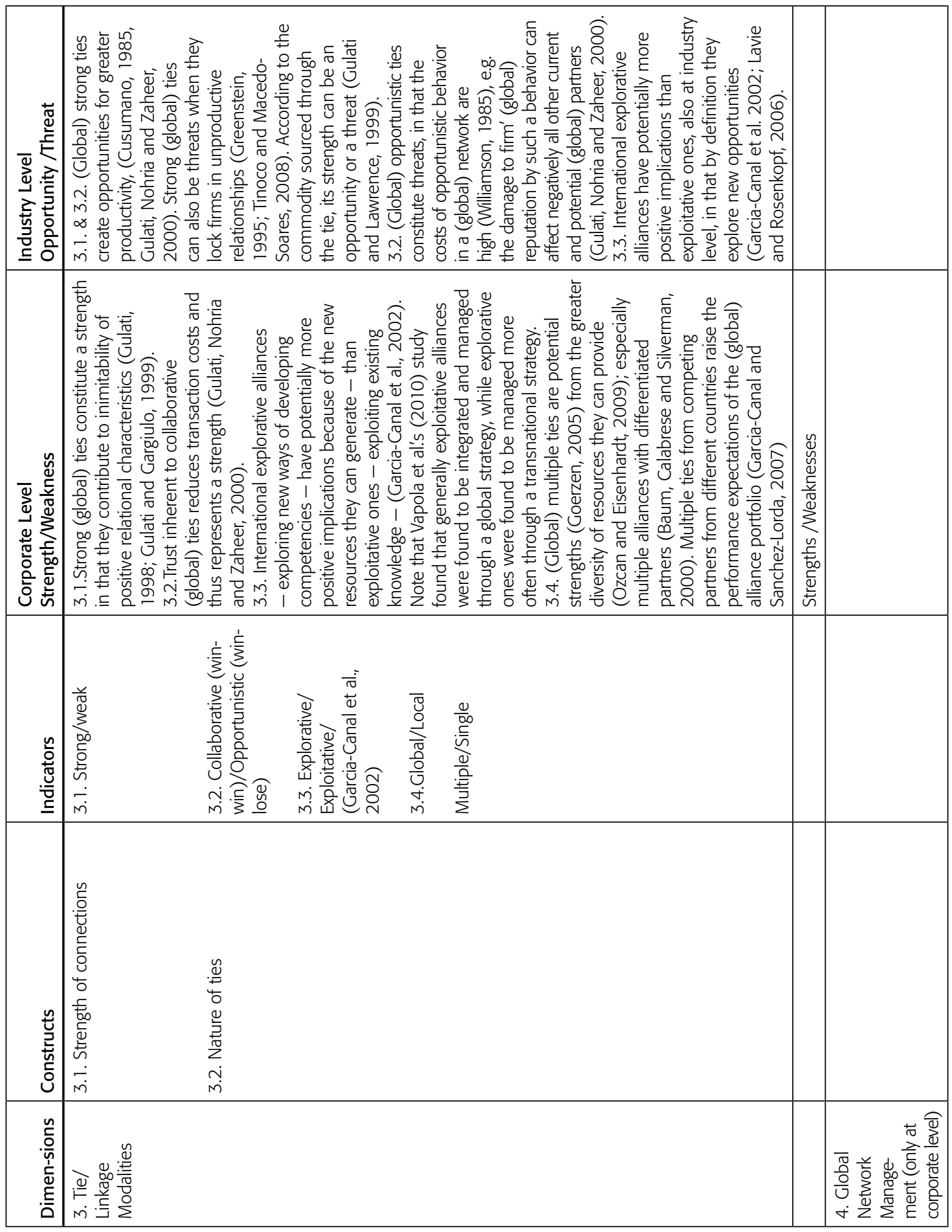


In the next section we explain the third component of the Global SNA framework.

\subsection{The Global SNA model}

Similarly to the other components of the framework proposed here, the Global SNA Model is an evolution and variation of the generic SNA model in that it includes the global dimension (figure 1). As its objective is to help map the network of ties/linkages that are important to the firm's operation in a global context, the model highlights the firm's main global alliances and other global linkages, including those between partners, that constitute the focal firm's global ego net within its wider global value net. This explains why the actors in the firm's value net with which it has not established strategic global alliances or other linkages are referred to as "other strategic actors". Similarly the non relational organizational factors pertinent to strategic management of firms that compete globally are not explicitly named in the model, to avoid diverting attention from network dimensions. This does not mean that these factors do not count. This merely means that the model concentrates strategic analysis on the network characteristics that are identified as strategically significant for the firm's operation in the global competitive scenario.

By using differences in size, shape and color (if applicable), the generic Global SNA model features a few of the essential constructs for each one of the three key network dimensions common to corporate and industry level analysis: network structure, composition, and tie modalities. The network structure construct depicted is density. The network composition constructs shown are: i) member status - represented by the relatively larger size of the actor-member as compared with the others in its category (e.g. supplier firm A is a much more important (resource-rich) one for the focal firm than supplier firm B), and ii) identity - indicated explicitly in terms of the member's role (e.g. supplier, customer). The constructs shown for tie modalities are i) strengths of connections, the fuller the line the stronger (more binding) the connection, ii) nature of the tie indicated by the direction of the arrows, when it is collaborative or explorative arrows appear at both ends of the tie, when opportunistic or exploitative merely an arrow is directed at the partner that is being taken advantage of. As an instrument for mapping the focal firm's global ego net, the model should also indicate the types of global alliances that constitute this net, in terms of the criteria adopted for their classification. When colors can be used, the rainbow spectrum is recommended to characterize the alliances in terms of the intensity of the relationship, with red lines corresponding to the high end - merger/ac- 
quisition or joint venture, and violet to the low end - agreement. In the case of a black and white version, the spectrum goes from black line - global merger/ acquisition or global joint venture, to black dotted line - agreement between foreign partners. In between, different shades of gray can be adopted (e.g. very dark gray lines for cross-equity ownership, less dark for minority equity investment, light gray for joint $R \& D$ etc.). To characterize the type of alliance in ter$\mathrm{ms}$ of its scope and orientation, different patterns (e.g. full as opposed to scotch patterned or hatched lines) can be used.

\section{Figure 1}

Global Strategic Network Analysis - SNA - model

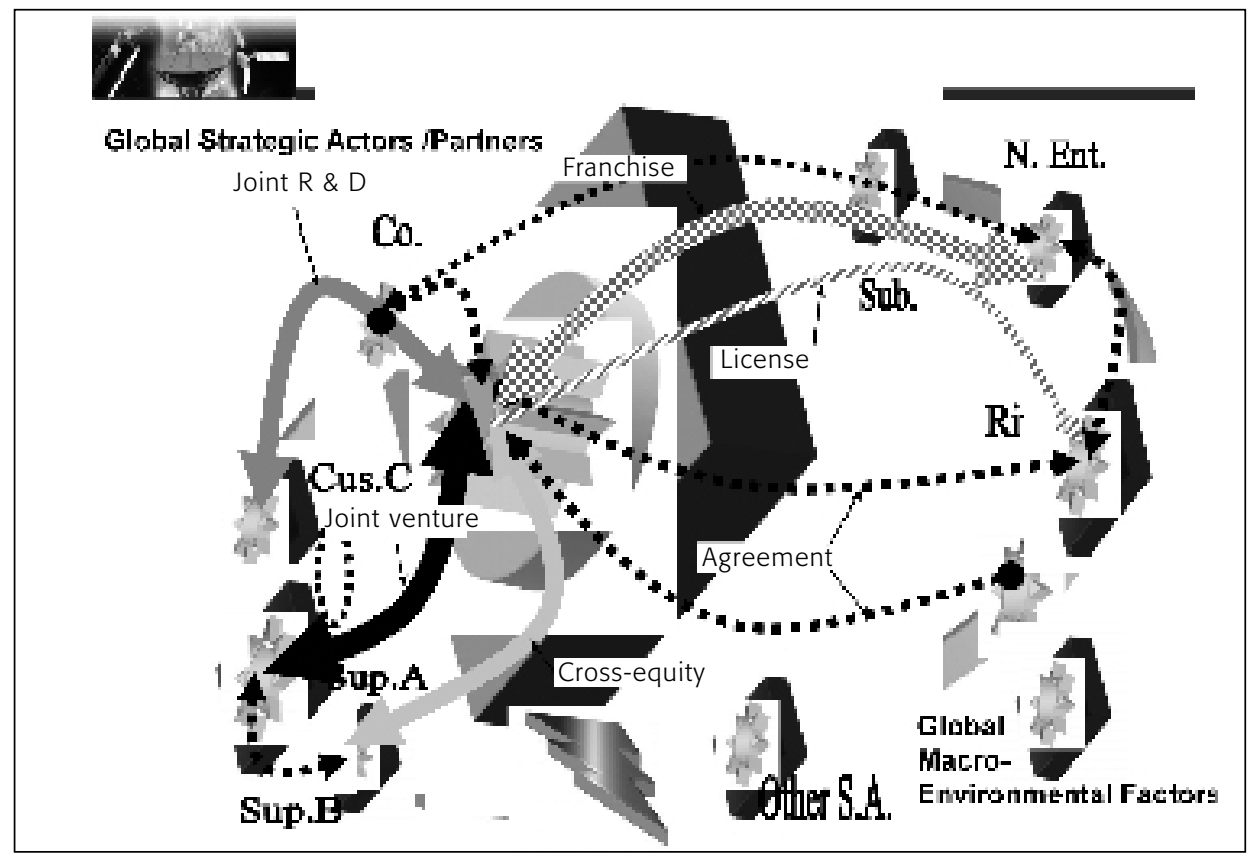

Cus. $=$ Customer; Sup. $=$ Supplier; Riv. = Rival; N. Ent.= New Entrant; Co. = Complementor; Sub. = Substitute; Other S.A. = Other Strategic Actors. $\Leftrightarrow=$ Collaborative/Explorative Alliance; $\Rightarrow=$ Opportunistic/Exploitative Alliance. The fuller the line is, the stronger the tie. For type of tie, see caption.

\section{Discussion and concluding remarks}

As the Global SNA framework has not yet been consolidated or fully validated empirically, it should be viewed as a working framework. In fact, several elements of this framework have to be further developed. Namely, reference lists 
for Steps 2 and 3 are still under construction and the reference list for Step 6 has to be refined. For example, further distinctions regarding relevant factors and their implications for the specific cases of, respectively, global and transnational strategies should be detailed in all the reference lists.

In spite of these limitations inherent to work in progress, there are indications that our proposal has the potential to capture new insights regarding the strategic implications of global alliances and networks that could not be found by way of the generic SNA framework because it does not include global relational constructs.

For example, the results of a few exploratory case studies of firms that operate globally (Keil, 2009; Macedo-Soares and Mendonça, 2010; Pereira, 2010), in whose scope some of our global relational constructs were tentatively used, strongly suggested that because of their global network characteristics, many of their global linkages could enhance the opportunities of non relational macro-environmental factors or even mitigate the latter's threats. A case in point was the high density of ties and centrality within the network of global telecom infrastructure firms that contributed to mitigate the threat of global new entrants into the industry.

Thus, even at its current stage, it is believed that the Global SNA framework can benefit both practitioners of firms that compete globally in alliances and networks and researchers that are investigating how to enhance the strategic management of these firms.

Regarding its applications in a research context, as we have already suggested, several measures have to be taken first of all to consolidate the Global SNA framework as a robust strategic analysis tool. After drawing up the missing reference lists, it is important to apply the framework, even in its draft form, in the scope of multiple case studies of firms that compete globally in alliances and networks, following Eisenhardt and Graebner's (2007) recommendations for theory building.

Given that firms are increasingly adopting transnational strategies, we recommend investigations focused on transnational firms in alliances and networks. Our framework could be applied in the scope of multiple case studies of these firms with a view to identifying constructs pertinent to their relational peculiarities.

Also, a variation of the Global SNA framework could be designed for the case of strategic groups of respectively global and transnational firms, where a global macro ego-net would be contemplated in the scope of its global macro value net, drawing on similar variations for strategic groups of the generic SNA framework (e.g. Macedo-Soares and Mendonça, 2010). 
Where practitioners are concerned we believe that the Global SNA framework, even in its current form, can provide at least a starting point for devising the sort of formal organizational rules and best practices to manage alliances and networks that Goerzen (2005) found to be lacking also in global firms. It could thus pave the way for becoming a both friendly and robust strategic analysis and management tool for firms that compete globally in alliances and networks, in keeping with the intention of our proposal.

\section{References}

AALTONEN, M. Sense-making in relation to time and the strategic landscape. In: AALTONEN, M. (Ed.). The third lens: multi-ontology sense-making and strategic decision-making. Burlington, USA: Ashgate Publishing Company, 2007. p. 15-26.

ANAND, B.N., KHANNA, T. Do firms learn to create value? The case of alliances. Strategic Management Journal, v. 21, Special Issue, p. 295-316, 2000.

ANDREWS, K. The concept of strategy. Irwin: Homewood, 1971.

AUSTIN, J.E. Managing in developing countries: strategic analysis and operating techniques. New York: The Free Press, 1990.

BAMFORD, J.; GOMES-CASSERES, B.; ROBINSON, M. Envisioning collaboration: mastering alliance strategies. San Francisco: Jossey-Bass, 2004.

BARNEY, J.B. Gaining and sustaining competitive advantage. New York: AddisonWesley, 1997.

BARTLETT, C.A.; GHOSHAL, S. Managing across borders: the transnational solution. Cambridge: Harvard Business School Press, 1989; (2 $\left.2^{\text {nd }} e d.\right) 1998$.

BASTOS, S.A.P.; MACEDO-SOARES, T. Diana L. van Aduard de. Impacto estratégico dos fatores macroambientais no desempenho de concessões de serviços públicos: a CEG e a CEG Rio na ótica relacional. Revista de Administração P[ublica, Rio de Janeiro, v. 41, p. 733-767, 2007.

BAUM, J.A.; CALABRESE C.T.; SILVERMAN, B.S. Don't go it alone: alliance network composition and startups' performance in Canadian biotechnology. Strategic Management Journal, v. 21, Special Issue, p. 267-294. 2000.

BELL, J.H.J. The internationalization of small computer software firms. European Journal of Marketing, v. 29, n. 8, p. 60-75, 1995. 
BRAMFORD, J.; ERNST, D. Measuring alliance performance. McKinsey on Finance, p. 6-10, Autumn 2002.

BRANDENBURGER, A.M.; NALEBUFF, B.J. Co-opetition, New York: Doubleday, 1997.

BUCKLEY, P.J.; GHAURI, P.N. Globalisation, economic geography and the strategy of multinational enterprises. Journal of International Business Studies, v. 35, p. 81-98, 2004.

; CASSON, M. C. The internalisation theory of the multinational enterprise: a review of the progress of a research agenda after 30 years. Journal of International Business Studies, v. 40, p. 1563-1580, 2009.

CHERNS, A.B. The principles of socio-technical design. Human Relations, v. 29, p. 783-792, 1976.

CHETTY, S.; BLANKENBURG HOLM, D. Internationalisation of small to mediumsized manufacturing firms: A network approach. International Business Review, v. 9, n. 1, pp. 77-93, 2000.

CONTRACTOR, F.J.; LORANGE, P. Why should firms cooperate? The strategy and economics basis for cooperative ventures. In: . Cooperative strategies in international business. Lexington, MA: Lexington Books, 1988. p. 3-28.

; WASSERMAN, S.; FAUST, K. Testing, multi-theoretical, multi-level hypotheses about organizational networks. Academy of Management Review, v. 31, n. 3, p. 681-703, 2006.

COOL, K.; SCHENDEL, D. Strategic group formation and performance: The case of the U.S. pharmaceutical industry 1963-1982. Management Science, v. 33, n. 9, p. 1102-1124, 1987.

COVIELLO, N.E. The network dynamics of international new ventures. Journal of International Business Studies, v. 37, p. 713-731, 2006.

; MUNRO, H. Network relationships and the internationalisation process of small software firms. International Business Review, v. 6, n. 4, pp. 361-386, 1997.

CUSUMANO, M.A. The Japanese automobile industry. Cambridge, MA: Harvard University Press, 1985.

DAS, T.K.; TENG, B. Alliance constellations: a social exchange perspective. Academy of Management Review, v. 27, p. 445-456. 2002

DOZ, Y.L.; Hamel, G. Alliance advantage. Boston, Mass.: Harvard Business School Press, 1998. 
; KOSONEN, M. Fasts. New York: Wharton School Publishing, 2008.

DUNNING, J.H.; LUNDAN, S.M. Multinational enterprises and the global economy. $2^{\text {nd }}$ Ed. Northampton, Mass.: Edward Elgar Publishing, 2008.

DYER, J.H.; NOBEOKA, K. Creating and managing a high-performance knowledgesharing network: the Toyota case. Strategic Management Journal, v. 21, Special Issue, p. 345-367, 2000.

; SINGH, H. The relational view. Academy of Management Review, v. 23, n. 4, p. 660-680, 1998.

EISENHARDT, K.M. Building theories from case study research. Academy of Management Review, v. 14, n. 4, p. 532-550, 1989.

; Graebner, M.E. Theory building from cases: opportunities and challenges. Academy of Management Journal, v. 50, n. 1, p. 25-32, 2007.

Fahey, L.; RANDALL, R.M. Learning from the future. New York: John Wiley, 1998.

FIEGENBAUM, A.; HART, S.; SCHENDEL, D. Strategic reference point theory. Strategic Management Journal, v. 17, n. 2, p. 219-235, 1996.

GALASKIEWICZ, J.; ZAHEER, A. Networks of competitive advantage. Research in the Sociology of Organizations, v. 16, p. 237-261, 1999.

GARCÍA-CANAL, E. et al. Accelerating international expansion through global alliances: a typology of cooperative strategies. Journal of World Business, v. 37. p. 91-107, 2002.

; SANCHEZ-LORDA, P. One more only if it is one of us. The number of partners and the stock market reaction to domestic and international alliance formation in EU telecoms firms. International Business Review, v. 16, n. 1, p. 83-108, 2007.

GARCIA-PONT, C.; NOHRIA, N. Local versus global mimetism: the dynamics of alliance formation in the automobile industry. Strategic Management Journal, v. 23, p. 307-321, 2002.

GERINGER, J.M.H.L. Measuring performance of international joint ventures. Journal of International Business Studies, v. 22, n. 2, p. 249-263, 1991.

GHEMAWAT, P. Redefining global strategy. Boston: Harvard Business School Press, 2007.

GHOSH, M.; JOHN, G. Governance value analysis and marketing strategy. Journal of Marketing, Special Issue, p. 131-143, 1999. 
GNYAWALI, D.R.; MADHAVAN, R. Cooperative networks and competitive dynamics: a structural embeddedness perspective. Academy of Management Review, v. 26, n. 3, p. 431-445, 2001.

GOMES-CASSERES, B. Group versus group: how alliance networks compete. Harvard Business Review, p. 62-74, July/Aug. 1994.

. The alliance revolution. London: Harvard University Press, 1996.

GOERZEN, A. Managing alliance networks: emerging practices of multinational corporations. Academy of Management Executive, v. 19, n. 2, pp. 94-108, 2005.

GRANOVETTER, M. Economic action and social structure: the problem of embeddedness. The American Journal of Sociology, v. 91, n. 3, pp. 481-510, Nov. 1985. GREENSTEIN, S.M. Lock-in and the costs of switching mainframe computer vendors in the US Federal Government in the 1970s. IEEE Annals of the History of Computing, v. 17, n. 3, p. 58-66, 1995.

GRIFFITH, D.A.; CAVUSGIL, S.T.; XU, S. Emerging themes in international business research. Journal of International Business Studies. v. 39, p. 1220-1235, 2008.

GULATI, R. Alliances and networks. Strategic Management Journal, v. 19, p. 293$317,1998$.

; GARGIULO, M. Where do interorganizational networks come from? American Journal of Sociology, v. 104, n. 5, p. 1439-1493, 1999.

; LAWRENCE, P. Organizing vertical networks: a design perspective. Paper presented at the SMJ Special Issue Conference, Northwestern University, 1999.

; NICKERSON, J. Interorganizational trust, governance form and exchange performance. Organization Science. v. 19, n. 5. p. 688-710, 2008.

; NOHRIA, N.; ZAHEER, A. Strategic networks. Strategic Management Journal, v. 21, p. 203-215, 2000.

HARRIGAN, K.R. Strategic alliances and partner asymmetries. Management International Review, v. 28, p. 53-72, 1988.

HARZING, A.-W. An empirical analysis and extension of the Bartlett and Ghoshal typology of multinational companies. Journal of International Business Studies, v. 31, n. 1, p. 101-120, 2000.

HITT, M.A.; AHLSTROM, D; DACIN, M.T.; LEVITAS, E; SVOBODINA, L. The institutional effects of strategic alliance partner selection in transition economies: China versus Russia. Organization Science, v. 15, p. 173-185, 2004. 
; IRELAND, R.D.; HOSKISSON, R.E. Strategic management: competitiveness and globalization. $8^{\text {th }}$ Ed. Mason, OH: South-Western Cengage Learning, 2009.

; PISANO, V. The cross-border merger and acquisition strategy. Management Research, v. 1, p. 133-144, 2003.

HOETKER, G.; MELLEWIGT, T. Choice and performance of governance mechanisms: matching alliance governance to asset type. Strategic Management Journal, v. 30, p. 1025-1044, 2009.

HOFER, C.; SCHENDEL, D.E. Strategy formulation: analytical concepts. New York: West Publishing Co. Paul, 1978.

HOFFMANN, W. Strategies for managing a portfolio of alliances. Strategic Management Journal, v. 28, n. 8, p. 827-856, 2007.

JOHANSON, J.; VAHLNE, J-E. The internationalization process of the firm: a model of knowledge and increasing foreign market commitment. Journal of International Business Studies, v. 8, n. 1, p. 23-32, 1977.

; ___ Business relationship learning and commitment in the internationalization process. Journal of International Entrepreneurship, v. 1, p. 83-101, 2003.

; ___. The Uppsala internationalization process model revisited: from liability of foreignness to liability of outsidership. Journal of International Entrepreneurship, v. 40, p 1411-1431, 2009.

KALE P.; SINGH, H. Building firm capabilities through learning: the role of the alliance learning process in alliance capability and success. Strategic Management Journal, v. 28, n. 10, p. 981-1000, 2007.

; _. Managing strategic alliances: what do we know now, and where do we go from here? Academy of Management Perspectives, p.45-61, Aug. 2009

; DYER, J.; SINGH, H. Alliance capability, stock market response and long-term alliance success: the role of the alliance function. Strategic Management Journal, v. 23, n. 8, p. 747-767, 2002.

; SINGH, H.; PERLMUTTER, H. Learning and protection of proprietary assets in strategic alliances. Strategic Management Journal, v. 21, p. 217-237, 2000.

KEIL, A.P.N. Gestão estratégica de empresas em redes de alianças num contexto global de grandes mudanças: foco nas empresas líderes fornecedoras de equipamentos de rede de telecomunicações. M.Sc. Thesis. - IAG, Pontifical Catholic University of Rio de Janeiro, Rio de Janeiro, 2009.

KNOKE, D. Changing organizations: business networks in the new political economy. Colorado: Westview, 2001. 
KOKA, B.R.; PRESCOTT, J.E. Designing alliance networks: the influence of network position, environmental change and strategy on firm performance. Strategic Management Journal, v. 29, p. 639-661, 2008.

KOZA, M.P.; LEWIN, A.Y. The co-evolution of strategic alliances. Organization Science, v. 9, pp. 255-264, 1998.

LASSERRE, P. Global strategic management. New York: Palgrave MacMillan, 2003.

LAVIE, D. Alliance portfolios and firm performance: a study of value creation and appropriation in the U.S. software industry. Strategic Management Journal, v. 28, p. 1187-1212, 2007.

; ROSENKOPF, L. Balancing exploration and exploitation in alliance formation. Academy of Management Journal, v. 49, n. 4, pp. 797-818, 2006.

LAZZARINI, S.G. The transition from alliance networks to multilateral alliances in the global airline industry. Brazilian Administration Review - BAR, v. 5, n. 1, p. 19-36, Jan./Mar. 2008.

. The impact of membership in competing alliance constellations: evidence on the operational performance of global airlines. Strategic Management Journal, v. 28, p. 345-367, 2007.

LEITE, J.C.; MACEDO-SOARES, T.D.L. v. A. Alianças e redes estratégicas no setor de downstream de petróleo no Brasil. Revista de Administração Pública, Rio de Janeiro, v. 39, p. 1319-1347, 2005.

LOANE, S.; BELL, J. Rapid internationalization among entrepreneurial firms in Australia, Canada, Ireland and New Zealand: an extension to the network approach. International Marketing Review, v. 23, n. 5, p. 467-485, 2006.

LUNNAN, R.; HAUGLAND, S. Predicting and measuring alliance performance: a multidimensional analysis. Strategic Management Journal, v. 29, n. 5, p. 545-556, 2008.

MACEDO-SOARES, T.D.L. v. A. Strategic alliances and networks: conceptual tools for strategic \ssessments. Readings book of GBATA Conference. Rome, 2002. p. 292-305.

. Ensuring dynamic strategic fit of firms in alliances and networks in a globalized context: proposing the Global SNA — Strategic Network Analysis — framework. Strategic Management Society — SMS Special Conference Finland, 2010. Disponível em: <http://finland.strategicmanagement.net/handouts.php $>$. 
; CHAMONE, S.G. Total quality strategies in industry. Quality Management Journal, v. 1, n. 3, p. 57-79, 1994.

et al. Assessing competitive strategies of foreign banks in Latin America. Journal of Global Business and Technology, v. 1, n. 1, p. 1-13, 2005.

; FIGUEIRA, L.A. Gestão estratégica da energia nucleoelétrica no Brasil: recursos e competências críticos para seu sucesso. Revista de Administração Contemporânea - RAC, v. 11, p. 55-76, 2007.

; LUCAS, D.C. Práticas gerenciais de qualidade das empresas líderes no Brasil. Rio de Janeiro: Qualitymark, 1996.

; MENDONÇA, A.P.G. Strategic implications of alliances and other linkages of leading Telecom operators in Brazil: network and international perspectives. Latin American Business Review, v.11, n. 1, p. 45-73, 2010.

; SCHUBSKY, A.M.G. Contribution of expatriates in the management of subsidiaries to the corporate governance of international firms: the case of Vale. Brazilian Administration Review - BAR, v. 7, n. 1, p. 98-114, 2010.

; TAUHATA, T.L. Ferramental para análise estratégica pela ótica relacional: resultados do seu teste piloto na CVRD. In: ENANPAD, XXVV. Anais..., 2002. (CD-ROM)

; TAUHATA, T.; FREITAS, J.C.T. Strategic implications of alliances and networks of horizontal portals in Brazil. Latin American Business Review, v. 5, p. 71-102, 2004.

; TAUHATA, T.; LIMA, F.C. Implicaciones estratégicas de las redes de alianzas en el sector de lineas aereas: estudio de caso practico. Revista de Empresa, Madrid, v. 13, p. 56-76, 2005.

MADHAVAN, R.; KOKA, B.R.; PRESCOTT, J.E. Networks in transition: how industry events (re)shape interfirm relationships. Strategic Management Journal, v. 19, p. 439-459, 1998.

MITSUHASHI, H.; SHANE, S.; SINE, W.D. Organization governance form in franchising: efficient contracting or organizational momentum? Strategic Management Journal, v. 29, p. 1127-1136, 2008.

MCEVILY. B.; ZAHEER, A. Bridging ties. Strategic Management Journal, v. 20, p. 1133-1156, 1999.

MINTZBERG, G.H.; QUINN, J.B.; GHOSHAL, S. The strategy process. London: Prentice Hall, 1995.

NOHRIA, N.; GARCIA-PONT, C. Global strategic linkages and industry structure. Strategic Management Journal, v. 12, p. 105-124, 1991. 
NIELSEN, B.B. Strategic fit, contractual and procedural governance in alliances. Journal of Business Research, 2009. doi:10.1016/j.jbusres.2009.05.001.

NIPPA, M.; BEECHLER, S.; KLOSSEK, A. Success factors for managing international joint ventures: a review and an integrative framework. Management and Organization Review, v.3, p. 277-310, 2007.

OVIATT, B.M.; MCDOUGALL, P.P. The internationalization of entrepreneurship. Journal of International Business Studies, v. 36, n. 1, pp. 2-8, 2005.

OZCAN, P.; EISENHARDT, K.M. Origin of alliance portfolios: entrepreneurs, network strategies and firm performance. Academy of Management Journal, v. 52, n. 2, p. 246-279, 2009.

PEREIRA, M.H.F. Implicações estratégicas das alianças e outras ligações internacionais na indústria de minério de ferro: o caso da Vale. M.Sc. Thesis. — IAG, Pontifical Catholic University of Rio de Janeiro, Rio de Janeiro, 2010.

PORTER, M. Competitive strategy. New York: The Free Press, 1980.

PRAHALAD, C.K.; DOZ, Y.L. The multinational mission: balancing local demands and global vision. NewYork: The Free Press, 1987.

PROVAN, K. G.; KENIS, P. Modes of network governance: structure, management and effectiveness. Journal of Public Administration Research and Theory, p. 1-24, Aug. 2007.

PURANAM, P.; VANNESTE, B. Trust and governance: untangling a tangled web. Academy of Management Review, v. 34, n. 1, p. 11-28, 2009.

ROWLEY, T.; BEHRENS, D.; KRACKHARDT, D. Redundant governance structures: an analysis of relational and structural embeddedness in the steel and semiconductor industries. Strategic Management Journal, v. 21, p. 369-386, 2000.

RUMELT, R.P.; SCHENDEL, D.; TEECE, D. Strategic management and economics. Strategic Management Journal, v. 12, p. 5-30, Winter 1991.

SIGGELKOW, N. Change in the presence of fit: the rise, the fall, and the renaissance of Liz Claiborne. Academy of Management Journal, v. 44, p. 838-857, 2001.

STONEHOUSE, G. et al. Global and transnational business: strategy and management. 2. ed. Chichester, West Sussex: John Wiley \& Sons, 2005.

TAVARES, M.; MACEDO-SOARES, T.D.L. v. A.. Alianças e redes estratégicas: as tendências nas empresas líderes no Brasil. Revista BNDES, Rio de Janeiro, n. 6, p. 293-312, 2003. 
TENG, B.S.; DAS, T.K. Governance structure choice in strategic alliances: the role of alliance objectives, alliance management experience and international partners. Management Decision, v. 46, n. 5, p. 725-742, 2008.

TINOCO, J.P.; MACEDO-SOARES, T.D.L. v. A. O lock-in estratégico em relacionamentos inter-organizacionais: o caso da Dataprev. Cadernos Ebape.Br, v. 6, n. 4, dez. 2008.

TROCCOLI, I.R.; MACEDO-SOARES, T.D.L. v. A. Novas estratégias da agroindústria brasileira de suco de laranja. Organizações \& Sociedade, v. 8, n. 2, p. 13-27, 2001.

UZZI, B. Social structure and competition in interfirm networks: the paradox of embeddedness. Administrative Science Quarterly, v. 42, p. 36-67, 1997.

VAN DER HEIJDEN, K. Scenarios. New York: John Wiley \& Sons, 1996.

PESQUISA da PUC mostra a tendência nas parcerias. Valor Econômico, 11 jun. 2002. Caderno B2.

VAPOLA, T.J.; PAUKKU, M.; GABRIELSSON, M. Portfolio management of strategic alliances: An International business perspective. International Business Review, v. 19, pp. 247-260, 2010.

VILLAS, M.; MACEDO-SOARES, T.D.L. v. A.; RUSSO, M.G. Bibliographical research method for business administration studies. Brazilian Administration Review - BAR, v. 5, p. 139-159, 2008.

YANG, H.; LIN, Z.J.; LIN, Y.L. A multilevel framework of firm boundaries: firm characteristics, dyadic differences and network attributes. Strategic Management Journal, v. 31, n. 3, p. 237-261, 2010.

YIN, R.K. Case study research: design and methods. London: Sage, 1994.

WANG, H.C.; HE, J.; MAHONEY, J.T. Firm-specific knowledge resources And competitive advantage: the roles of economic and relationship-based employee governance mechanisms. Strategic Management Journal, v. 30, p. 1265-1285, 2009.

WERNERFELT, B.A. A resource-based view of the firm. Strategic Management Journal, v. 5, n. 2, p. 171-180, 1984.

WESTNEY, D.E. Cross-Pacific internationalization of R\&D by U.S. and Japanese firms. R\&D Management, v. 23, n. 2, p. 171-181, 1993.

WIERSEMA, M.F.; BOWEN, H.P. Corporate diversification: the impact of foreign competition, industry globalization and product diversification. Strategic Management Journal, v. 29, p. 115-132, 2008. 
WILLIAMSON, O. The economic institutions of capitalism. New York: Free Press, 1985.

ZAHEER, A.; ZAHEER, S. Catching the wave: alertness, responsiveness, and market influence in global electronic networks. Management Science, v.43, n. 11, p. 1493-1509, 1997.

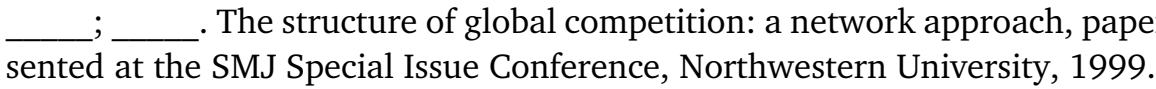

ZAJAC, E.J.; KRAATZ, M.S.; BRESSER, R.K.F. Modeling the dynamics of strategic fit. Strategic Management Journal, v. 21, p. 429-453, 2000. 